\title{
CAMBRIDGE
}

\section{Medicine and Public Health} in Latin America

A History

Marcos Cueto and Steven Palmer

New Approaches to the Americas

$\$ 80.00$ / f55.00: HB: 978-1-107-02367-3

\$29.99 / f19.99: PB: 978-1-107-63301-8: 318 pp.

The Women of Colonial

\section{Latin America}

Second Edition

Susan Migden Socolow

New Approaches to the Americas

$\$ 80.00$ / f50.00: HB: 978-0-521-19665-9

\$27.99 / f17.99: PB: 978-0-521-14882-5: 272 pp

\section{The Colonial Caribbean}

Landscapes of Power in

Jamaica's Plantation System

James A. Delle

Case Studies in Early Societies

$\$ 90.00$ / f55.00: HB: 978-0-521-76770-5

\$32.99 / f20.99: PB: 978-0-521-74433-1: 266 pp.

\section{Democracies and}

Dictatorships in Latin America

Emergence, Survival, and Fall

Scott Mainwaring and

Aníbal Pérez-Liñán

$\$ 85.00$ / f55.00: HB: 978-0-521-19001-5

\$29.99 / f19.99: PB: 978-0-521-15224-2: 368 pp.

\section{Hierarchical Capitalism in} Latin America

Business, Labor, and the Challenges of Equitable Development

\section{Ben Ross Schneider}

Cambridge Studies in Comparative Politics

$\$ 80.00$ / f55.00: HB: 978-1-107-04163-9

\$27.99 / f19.99: PB: 978-1-107-61429-1: 259 pp.

\section{A Concise History of Brazil} Second Edition

Boris Fausto

With contributions by Sergio Fausto

Cambridge Concise Histories

\$85.00 / f55.00: HB: 978-1-107-03620-8

\$29.99 / f19.99: PB: 978-1-107-63524-1: 456 pp.

\section{Aztec Archaeology and Ethnohistory}

Frances F. Berdan

Cambridge World Archaeology

$\$ 90.00$ / f60.00: HB: 978-0-521-88127-2

\$32.99 / f21.99: PB: 978-0-521-70756-5: 364 pp.

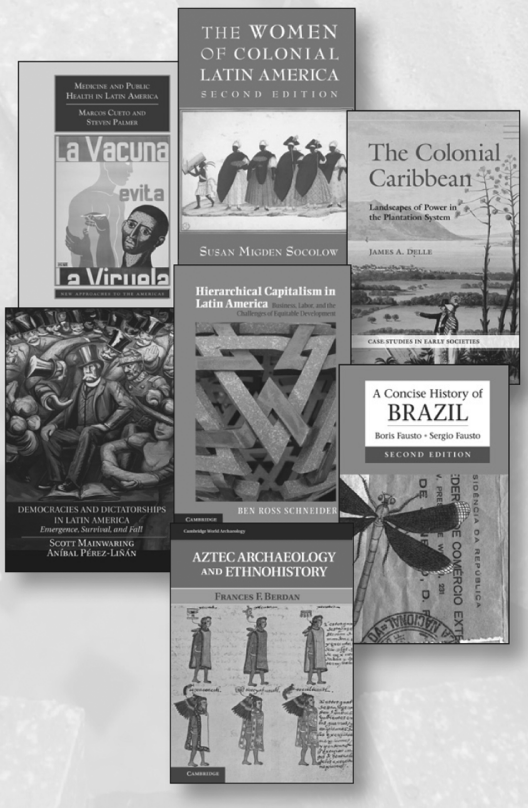

Prices subject to change. 


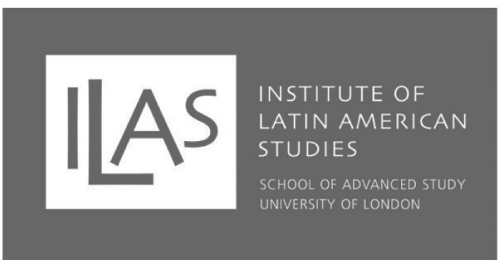

The Institute of Latin American Studies, administrative home of the Journal of Latin American Studies, is a national coordinating centre dedicated to serving the UK's Latin American and Caribbean studies community. Internationally recognised as a centre of excellence for research facilitation, it serves the wider community through organising academic events, providing online research resources, publishing scholarly writings and hosting visiting fellows. It possesses a world-class library dedicated to the study of Latin America.

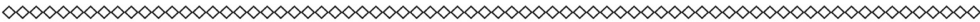

\section{Forthcoming Events}

Saturday 1 November 2014, 10am

Latin American Music Seminar

The Chancellor's Hall (Senate House, First Floor)

In collaboration with the Institute of Musical Research

Convenor: Dr Henry Stobart, Royal Holloway University of London

Monday 3 November 2014, 11:30am

Remembrance and Bereavement and the Mexican Day of the Dead

The Beveridge Hall (Senate House, Ground Floor)

In collaboration with the the National Council for Palliative Care

Thursday 27 November 2014, 6pm

Transatlantic Chilean Folk Ensemble

Deller Hall (Senate House, Basement)

Convenor: Dr Katia Chornik, University of Manchester

Saturday 6 December 2014, 10am

South American Archaeology Seminar

Venue: Institute of Archaeology

Convenor: Dr Bill Sillar, University College London

Our up to date programe is available at http://events.sas.ac.uk/ilas/events/list

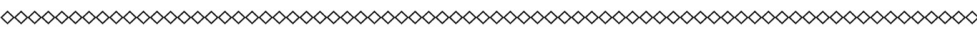

\section{Teaching}

The Institute of Latin American Studies runs, in collaboration with the Human Rights Consortium (HRC), a Latin American specialist pathway in the MA in Understanding and Securing Human Rights. This pathway enables students with a particular regional interest to focus their study of human rights on Latin America while continuing to benefit from the interdisciplinary, practice-focused nature of the MA in Understanding and Securing Human Rights, the longest-running MA in human rights of its kind in the UK. The Latin American pathway of the MA is one of the only specialist, Latin America-focused human rights degrees in the world, offering a unique opportunity to postgraduate students wishing to specialise in this field.

To find out more, please email ILAS@sas.ac.uk

Institute of Latin American Studies

School of Advanced Study, University of London

Senate House, Malet Street, London, WC1E 7HU

www.ilas.sas.ac.uk ILAS@sas.ac.uk 


\section{International Journal of Middle East Studies}

Published under the auspices of the Middle East Studies Association of North America

\section{Editor-in-Chief}

Akram Khater, North Carolina State University, USA Managing Editor

Jeffrey Culang, CUNY Graduate Center, USA

The International Journal of Middle East Studies publishes original research on politics, society and culture in the Middle East from the seventh century to the present day. The journal also covers Spain, south-east Europe, Africa, and parts of South Asia and the former Soviet Union for subjects of relevance to Middle Eastern civilization. Particular attention is paid to the history, politics, economics, anthropology, sociology, literature, and cultural studies of the area and to comparative religion, theology, law, and philosophy. Each issue contains approximately 50 pages of detailed book reviews.

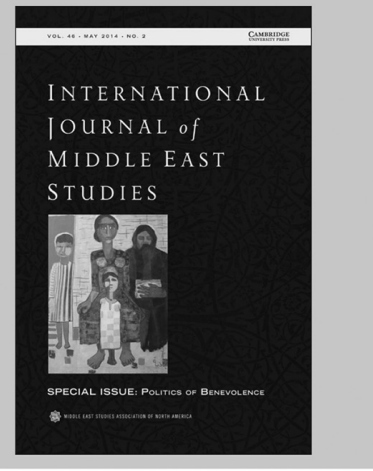

International Journal of Middle East Studies

is available online at: http://journals.cambridge.org/mes

\section{To subscribe contact Customer Services}

\section{in Cambridge:}

Phone +44 (0)1223 326070

$\mathrm{Fax}+44(0) 1223325150$

Email journals@cambridge.org

\section{in New York:}

Phone +1 (845) 3537500

$\mathrm{Fax}+1$ (845) 3534141

Email

subscriptions_newyork@cambridge.org

\section{Free email alerts}

Keep up-to-date with new material - sign up at

journals.cambridge.org/register 


\section{Perspectives on Politics}

Published for the American Political Science Association

\section{Editor}

Jeffrey C. Isaac, Indiana University, USA

Perspectives on Politics seeks to provide a space for broad and synthetic discussion within the political science profession and between the profession and the broader scholarly and reading publics. Such discussion necessarily draws on and contributes to the scholarship published in the more specialized journals that dominate our discipline. At the same time, Perspectives seeks to promote a complementary form of broad public discussion and synergistic understanding within the profession that is essential to advancing research and promoting scholarly community.

Perspectives seeks to nurture a political science public sphere, publicizing important scholarly topics, ideas, and innovations, linking scholarly authors and readers, and promoting broad reflexive discussion among political scientists about the work that we do and why this work matters.

Perspectives on Politics is sold ONLY as part of a joint subscription with American Political Science Review and PS: Political Science \& Politics.

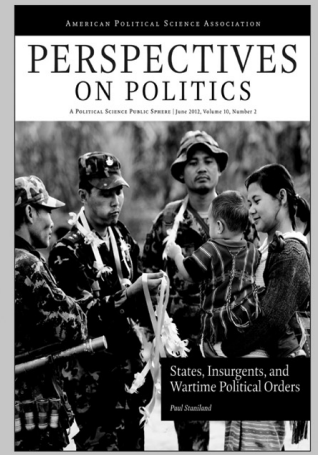

Perspectives on Politics is available online at: http://journals.cambridge.org/pps

\section{To subscribe contact} Customer Services

\section{in Cambridge:}

Phone $+44(0) 1223326070$

$\mathrm{Fax}+44(0) 1223325150$

Email journals@cambridge.org

\section{in New York:}

Phone +1 (845) 3537500

$\mathrm{Fax}+1(845) 3534141$

Email

subscriptions_newyork@cambridge.org

\section{Free email alerts}

Keep up-to-date with new material - sign up at

journals.cambridge.org/register 


\section{Revista de Historia Económica}

Journal of Iberian and Latin American Economic History

Published for Instituto Figuerola de Historia y Ciencias Sociales, Universidad Carlos III de Madrid

\section{Chief Editor}

Blanca Sánchez Alonso, Universidad CEU-San Pablo, Madrid, Spain Co-editors

Sandra Kuntz Ficker, El Colegio de México, Mexic

William Summerhill, UCLA, USA

Revista de Historia Económica - Journal of Iberian and Latin American Economic History (RHE-JILAEH) welcomes contributions with comparative approaches, especially those that include a wide geographical or global coverage. The journal will promote the presentation of new topics, ideas and perspectives from the different social sciences, notably new historical and economic methods. RHE-JILAEH publishes original research papers on economic history, economic thought and all those areas of economics concerned with long-term analysis. The geographical area addressed in these papers should preferably cover Spanish and Portuguese speaking countries and wider areas including any of these countries.

RHE-JILAEH is pleased to announce that it has been ranked 14th out of 69 journals in the history category, with an impact factor of 0.545 in the latest (2012)

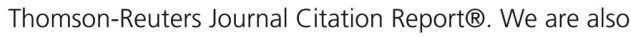
indexed in the History of Social Science category, as well as in History and Economics.

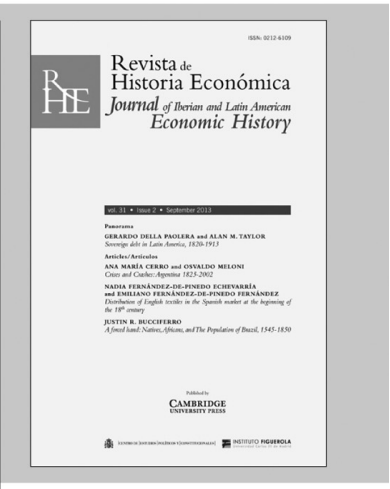

Revista de Historia Económica is available online at:

http://journals.cambridge.org/rhe

\section{To subscribe contact Customer Services}

\section{Americas:}

Phone +1 (845) 3537500

$\mathrm{Fax}+1$ (845) 3534141

Email

subscriptions_newyork@cambridge.org

\section{Rest of world:}

Phone +44 (0)1223326070

Fax +44 (0)1223 325150

Email journals@cambridge.org

\section{Free email alerts}

Keep up-to-date with new material - sign up at

journals.cambridge.org/register 


\section{World \\ Trade Review}

Editor

L. Alan Winters, University of Sussex, UK

The World Trade Review was established at the initiative of the Secretariat of the World Trade Organization (WTO) in close cooperation with Cambridge University Press. It is an independent journal - the Editor and all but one member of the Editorial Board are drawn from university faculties - that includes articles written from economic, legal, political and inter-disciplinary perspectives on issues of relevance to the multilateral trading system. Priority is given to papers that, along with being academically rigorous, are also accessible to government policy officials and the wider public. The journal also includes shorter articles seeking to rebut or challenge published papers.

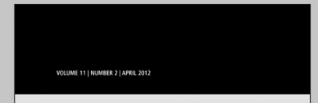

WORLD

TRADE

REVIEW

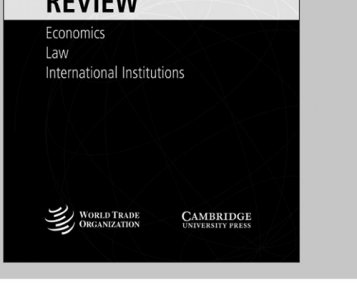

World Trade Review

is available online at:

http://journals.cambridge.org/wtr

\section{To subscribe contact} Customer Services

\section{Americas:}

Phone +1 (845) 3537500

$\mathrm{Fax}+1(845) 3534141$

Email

subscriptions_newyork@cambridge.org

\section{Rest of world:}

Phone +44 (0)1223 326070

$\mathrm{Fax}+44(0) 1223325150$

Email journals@cambridge.org

\section{Free email alerts}

Keep up-to-date with new material - sign up at

journals.cambridge.org/register 


\section{Editorial Policy}

The Journal of Latin American Studies is published four times a year, in February, May, August and November. Its editorial offices are located at the Institute of Latin American Studies, University of London. The editorial board comprises area studies specialists based in the United Kingdom from all the principal social science disciplines, including history.

The Journal aims to publish recent research in the field of Latin American studies in economics, geography, politics, international relations, sociology, social anthropology and history. Articles on literature and the arts are not normally included, but the editors are pleased to consider contributions in the field of intellectual and cultural history. Articles with an interdisciplinary approach are particularly welcome.

\section{Manuscript Submission (visit http://mc.manuscriptcentral.com/jlas)}

Articles submitted to the Journal should be original contributions. They should not be under consideration by another journal, nor have been published or be awaiting publication elsewhere. Translations of articles that have already been published will not be accepted. If an author is publishing a closely related article elsewhere, this fact should be stated in a cover note to the editors. Authors of articles published in the Journal assign copyright to Cambridge University Press (with certain rights reserved) and will receive a copyright assignment form for signature on acceptance of their paper.

Articles should be between 10,000 and 12,000 words, including footnotes, tables etc. The Journal is published in English, but articles may also be submitted in Spanish or Portuguese for peer review; if accepted for publication, the responsibility for translating articles rests with the author.

For full instructions on submissions and journal style, visit www.journals.cambridge. org/las/ifc.

The Journal publishes commissioned book reviews in each issue. Not all books received can be reviewed, and editorial policy gives preference to reviews of books regarded as being of major importance for the disciplines covered by the Journal. Unsolicited reviews cannot be considered.

Contributors are responsible for obtaining permission to reproduce any material for which they do not own copyright, to be used in both print and electronic media, and for ensuring that the appropriate acknowledgements are included in their manuscript.

All editorial correspondence should be addressed to The Editors, Journal of Latin American Studies, Institute of Latin American Studies, University of London, Senate House, Malet Street, London WC1E7HU, UK, or sent to jlas@sas.ac.uk.

\section{Proofs}

Proofs of accepted articles will be sent to authors as pdf files for checking and correction of typesetting errors. Typographical or factual errors only may be changed at proof stage. The publisher reserves the right to charge authors for correction of non-typographical errors.

\section{Offprints}

Contributors will receive a pdf file of their article.

This issue has been printed on FSC-certified paper and cover board. FSC is an independent, non-governmental, not-for-profit organisation established to promote the responsible management of the world's forests. Please see www.fsc.org for information.

\section{CAMBRIDGE UNIVERSITY PRESS}

The Edinburgh Building, Cambridge CB2 8RU, United Kingdom

32 Avenue of the Americas, New York, NY IOoI3-2473, USA

477 Williamstown Road, Port Melbourne, vic 3207, Australia

C/Orense, 4, Planta 1328020 Madrid, Spain

Lower Ground Floor, Nautica Building, The Water Club,

Beach Road, Granger Bay, 8005 Cape Town, South Africa

Printed in the UK by Bell \& Bain 


\section{Journal of Latin American Studies}

volume 46 : part 4 : November 2014

\section{Articles}

637 Ideas and Leaders in Contentious Politics: One Parish Priest in

El Salvador's Popular Movement

Peter M. Sanchez

663 The Genesis and Internal Dynamics of El Salvador's People's

Revolutionary Army, 1970-1976

Alberto Martín Álvarez and Eudald Cortina Orero

691 'Patria, Honor y Fuerza': A Study of a Right-Wing Youth Movement in Mexico during the 1930-1960s

Claire Brewster and Keith Brewster

723 A Preponderance of Politics: the Auténtico Governments and US-Cuban Economic Relations, 1945-1951

Vanni Pettinà

755 Constitutional Projects for the Division of Powers in Mexico during Iturbide's Empire, 1821-1823

Catherine Andrews

785 Book Reviews

841 Books Received

Cambridge Journals Online For further information about this journal please go to the journal website at: journals.cambridge.org/las

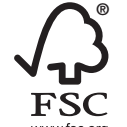

www.fsc.org
MIX

Paper from responsible sources FSC ${ }^{\circledR}$ C007785
CAMBRIDGE UNIVERSITY PRESS 